Review Article

\title{
Photobiomodulation: An Effective Approach to Enhance Proliferation and Differentiation of Adipose-Derived Stem Cells into Osteoblasts
}

\author{
Daniella Da Silva $\mathbb{D}$, Anine Crous $\mathbb{D}$, and Heidi Abrahamse \\ Laser Research Centre, Faculty of Health Sciences, University of Johannesburg, P.O. Box 17011, Doornfontein, Johannesburg, South \\ Africa 2028 \\ Correspondence should be addressed to Heidi Abrahamse; habrahamse@uj.ac.za
}

Received 1 October 2020; Revised 7 March 2021; Accepted 11 March 2021; Published 24 March 2021

Academic Editor: Darius Widera

Copyright (c) 2021 Daniella Da Silva et al. This is an open access article distributed under the Creative Commons Attribution License, which permits unrestricted use, distribution, and reproduction in any medium, provided the original work is properly cited.

\begin{abstract}
Osteoporosis is regarded as the most common chronic metabolic bone condition in humans. In osteoporosis, bone mesenchymal stem cells (MSCs) have reduced cellular function. Regenerative medicine using adipose-derived stem cell (ADSC) transplantation can promote the growth and strength of new bones, improve bone stability, and reduce the risk of fractures. Various methods have been attempted to differentiate ADSCs to functioning specialized cells for prospective clinical application. However, commonly used therapies have resulted in damage to the donor site and morbidity, immune reactions, carcinogenic generation, and postoperative difficulties. Photobiomodulation (PBM) improves ADSC differentiation and proliferation along with reducing clinical difficulties such as treatment failures to common drug therapies and late initiation of treatment. PBM is a noninvasive, nonthermal treatment that encourages cells to produce more energy and to undergo self-repair by using visible green and red and invisible near-infrared (NIR) radiation. The use of PBM for ADSC proliferation and differentiation has been widely studied with multiple outcomes observed due to laser fluence and wavelength dependence. In this article, the potential for differentiating ADSCs into osteoblasts and the various methods used, including biological induction, chemical induction, and PBM, will be addressed. Likewise, the optimal laser parameters that could improve the proliferation and differentiation of ADSC, translating into clinical success, will be commented on.
\end{abstract}

\section{Introduction}

Osteoporosis is a painful, chronic bone disease in humans, and its incidence is increasing globally [1]. Osteoporosis is characterized by the overall decrease in bone facets which brings about the fragility of bones and a highly probable risk of fractures [2]. At present, while therapy is still successful to some degree, there is a large discrepancy in the care of this disease. Regenerative medicine is considered a possible solution by the medical science world. The aim is to heal and treat diseased, impaired, or age-related tissue complications [3]. Currently, standing at the frontlines of regenerative medicine is stem cell therapy, due to the ability of stem cells to self- renew and differentiate into various cell types [4]. Stem cells have the unique ability of branching into numerous cell types, one of which is adipose-derived stem cells (ADSCs) [5]. ADSCs have the ability of differentiating into a specialized cell line through the use of various growth factors and physical factors [6]. PBM is understood to enhance the proliferation and differentiation of cells [7]. However, the numerous but unestablished methodologies to this technique must still be developed and pursued for a recognizable difference in stem cell therapy. This review focused on research outcomes of successful ADSC differentiation into osteogenic cell lineages. The selected thirty-one result articles summarized in the tables provided involved the use of chemical 
and biological growth factor inducers, PBM, and their combination for the purposes of cell differentiation. This is to reveal the potential of this particular regenerative therapy as a worthwhile in vitro pursuit for successful clinical studies and produce an enhanced form of treatment for osteoporosis.

\section{Literature Review}

2.1. Osteoporosis. Osteoporosis is a life-long skeletal disease [8] that is increasingly becoming a global epidemic [9]. Osteoporosis is defined as a decrease in bone mass, a decrease in bone density, and an overall deterioration of bone $[2,10]$. This results in the weakening of bones which raises the incidence of fracture risks [10]. The World Health Organization (WHO) criteria define osteoporosis as a disease where the bone mass density (BMD) falls within a 2.5 standard deviation or lower than the average value [11]. The greater part of fractures tends to happen between the $-2.5<T-$ score $<-1$ range [12]. A discrepancy in bone resorption and development is the means through which osteoporosis develops [13] and is caused by a decrease in bone-forming mature osteoblast populations. This decrease in osteoblast populations is caused by multiple factors such as mesenchymal stem cells (MSCs) altering their biology, osteoblast progenitors that lack proliferation ability, a rise in apoptosis, and an increase in the build-up of marrow adipocytes [14-16]. As it stands, it is estimated that osteoporosis affects two hundred million individuals, and approximately nine million fractures that occur per year are brought on by osteoporotic disease [17]. Osteoporosis is understood to be unbiased to a specific gender, race, or age; therefore, it has the ability to affect a variety of individuals [11]. However, this disease has shown a tendency of affecting Caucasians, elderly population groups, and specifically postmenopausal females [18]. Osteoporosis is problematic as it affects the quality of life of a patient through financial burden, increasing probable painful fractures as well as morbidity and mortalities [19]. Osteoporotic treatment currently remains limited as most treatments, which are drug-based therapies, create severe side effects such as osteonecrosis of the jaw and atypical femoral fractures $[20,21]$ and may raise breast cancer, stroke, and cerebral infarction risks if used for extended periods [22].

2.2. Bone Marrow Stromal Cells. Bone marrow stromal cells (BMSCs) comprise of a subset of stem cells known as MSCs, multipotent stromal cells, or skeletal stem cells, which are able to differentiate into osteoblasts and take part in an essential role within the "tissue engineering" of new bone [23]. Current studies have identified BMSCs, when featured in syngeneic, allogeneic, and xenogeneic situations, to exhibit immunoregulatory traits [24]. BMSCs are regarded as rejection tolerant supposed by their secretion of varying immunosuppressive factors and minimal MHC molecule expression; thus, a surge in immune reaction postinjection does not occur [25]. Despite the minimal MHC molecule expression, BMSCs are capable of NK cell induced lysis defence due to numerous mechanisms [26]. A majority of studies suggest that BMSCs stimulate the adaptive immunity in combination of production of their specific memory T cells [27] within a small period of time postinfusion into a host and disappear after approximately two to four days [24]. In summary, BMSCs secrete soluble factors that induce regulatory $\mathrm{T}$ cell and anti-inflammatory M2 monocyte/macrophage production. In company of these cells, BMSCs restrain helper T cells, B cells, NK cells, and mast cells' functions. Skeletal progenitors located within the bone marrow cavity are accountable for the formation of the 3-dimensional skeletal structure that provides a hematopoietic niche, due to osteoblasts, chondroblasts, adipocytes, and stromal fibroblasts' differentiation [28]. MSCs were originally designated over 25 years ago to describe a class of human and mammalian bone marrow and periosteum cells that could be isolated and grown in culture while preserving their in vitro potential to induce a range of mesodermal phenotypes and tissues [29]. These nonhematopoietic cells were first identified by Friedenstein et al. in the bone marrow, identified as a spindle in shape and displayed properties of stem cells $[30,31]$. Following this discovery, MSCs were extracted from adipose [32], muscle [33], and umbilical cord [34] sources. Today, these cells are known to reside in a majority of tissues like the bone marrow, muscle, fat tissue, and liver [35]. MSCs are acknowledged as adult stem cells because of their multipotency and self-renewal abilities [36]. MSCs are only regarded as such if their appearance is fibroblast-like and are able to differentiate into either osteogenic, adipogenic, or chondrogenic cell lineages [37]. MSCs even possess a special subset of cells referred to as dental pulp stem cells (DPSCs) which display effortless stimulation in osteogenic differentiation [38], particularly desirable for dentistry applications. Both bone marrow-derived mesenchymal stem cells (BMDMSCs) and ADSCs have been the commonly studied and characterized cell sources [37]. BMDMSCs are located in the bone marrow and harvested through a bone marrow aspiration under a local sedation which yields low cell numbers and has a tendency to differentiate into osteogenic cell type [39]. BMDMSCs function foremost as osteogenic progenitors as well as regulate hematopoietic stem cell (HSC) function through the secretion of trophic factors and maintenance of the HSC niche [36]. ADSCs are located in adipose tissue and harvested from minimally invasive lipoaspirates which yield large cell amounts and are better able to differentiate into a variety of cell types particularly adipocytes, osteoblasts, and chondrocytes making these cells a preferred cell choice [39].

2.3. Osteoblasts. The bone remodelling process consists of two significant processes, the one being bone resorption which is enabled by osteoclast cells [40] and the other being the development of new bone which is the responsibility of the osteoblast cells [41]. MSCs produce osteoblasts with the assistance of transcription factors like Osterix, runt-related transcription factor 2 (Runx2), octamer-binding transcription factor 3/4 (Oct4), and L-myc [42]. These significant functions of osteoblasts are to preserve and renew bone mass, control the quality of bone, and regulate overall skeletal performance [43-45]. Osteoblasts perform their significant functions by the creation and release of a variety of proteins needed for the formation of bone as well as the 


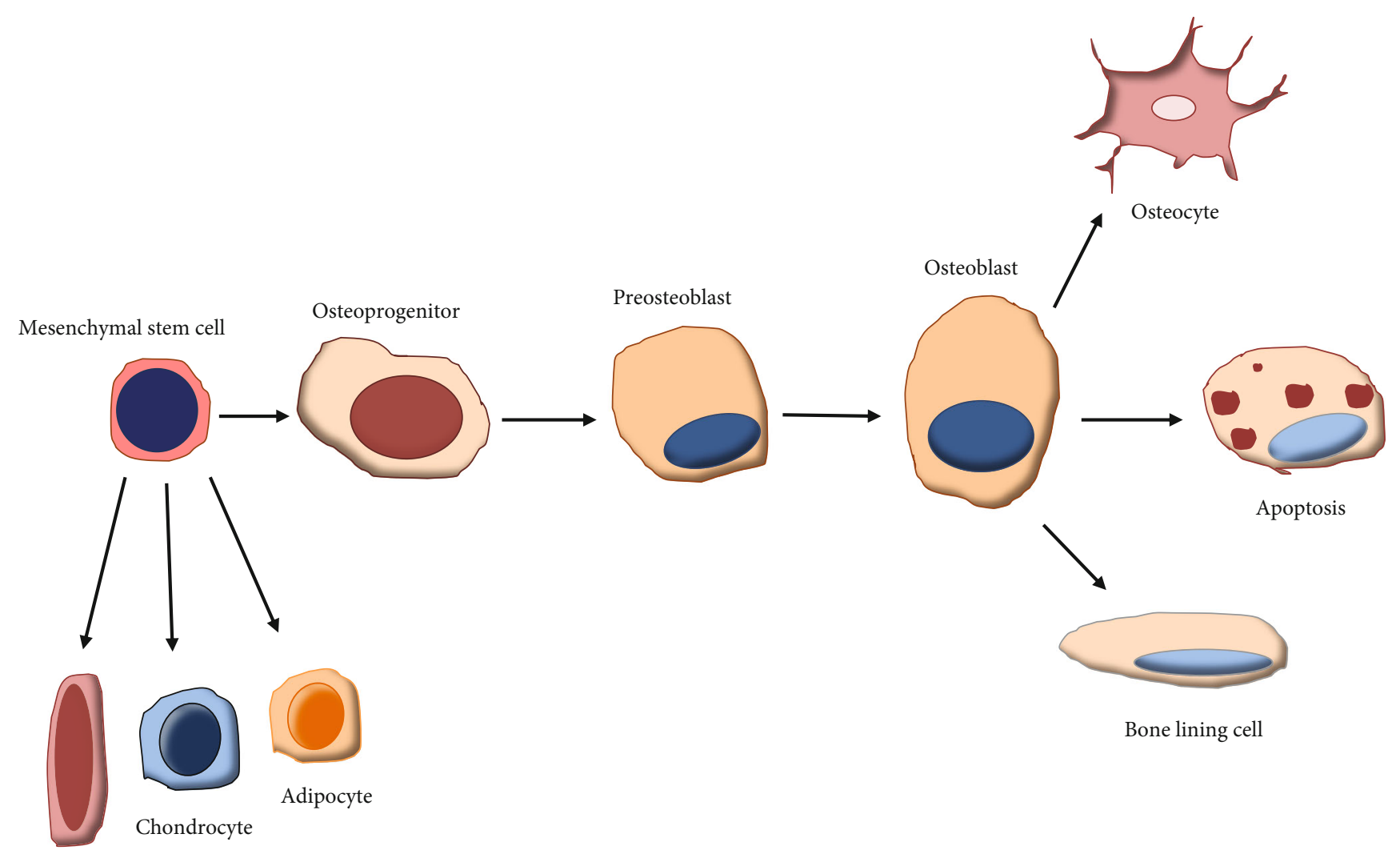

Myoblast

FIgURE 1: Osteogenic lineage. The process of osteogenic differentiation of MSCs.

mineralization of the bone matrix [46]. Osteoblast performance is affected by a range of influences such as the interactions of the cellular matrix [47], transcriptional and epigenetic mechanisms [48], inflammatory activities [49], and cell to cell communication [50]. As displayed in Figure 1, in the beginning of osteogenesis, MSC populations will continuously proliferate until committed to osteoblasts as this then decreases the rate of their proliferation. During the matrix maturation phase, early osteoblasts will secrete osteogenic markers like alkaline phosphatase, followed by the mineralization phase, where late osteoblasts secrete osteocalcin. At the end of bone formation, these cells will either develop into bone lining cells and osteocytes or submit to apoptosis [40].

2.4. Regenerative Medicine. Regenerative medicine is a developing field of medical science that is aimed at repairing the functionality and heal tissues or organs that have become diseased, injured, or affected by age-related complications [3]. Regenerative medicine emerged as a strategy to address the lack of available donor organs and tissues as well as critical immune rejection responses [51]. To influence the healing of tissue, restorative cells need to properly influence both the structure and function of new tissues. This is done using numerous combinations of both biological and chemical compounds and newly produced cells [52]; this is the basis of regenerative medicine (see Figure 2) [53].
The materials used for regenerative medicine are a significant aspect as they influence structure and function of the new tissue, offer growth factors, and control the behaviour of cells by imitating the extracellular matrix [54]. Recently approved Food and Drug Administration (FDA) regenerative medicine products have either improved or have remained similar to previous products [55]. This promotes both healing and regeneration; however, there still remains a gap in the treatment of disease [56]. Currently, stem cell therapy is taking the lead in the field of regenerative medicine because of SCs' remarkable ability to differentiate into multiple cell types and to unlimitedly self-renew [3].

2.5. Biomaterials/Scaffolds in Regenerative Therapy. Tissue engineering is an advancing tool for the regeneration of bone; the blend of cells, scaffolds, and biofactors often leads to a successful outcome. The scaffold is a bone tissue engineering (BTE) tool intended to trounce autografting and allografting shortcomings [57]; this is a 3D matrix designed for cells with an osteogenic affinity to attach and proliferate on the scaffold surface [58]. Two significant characteristics for a bone scaffold are to be (i) osteoconductive, the inner relocation of mesenchymal cells, osteoblasts, osteoclasts, and additional vasculature is to be offered by the scaffold, and (ii) osteoinductive, the stimulation of cells of different cell lineages to be differentiated into an osteogenic cell lineage [59]. Adult stem cells, particularly human bone marrow stem cells, are commonly 


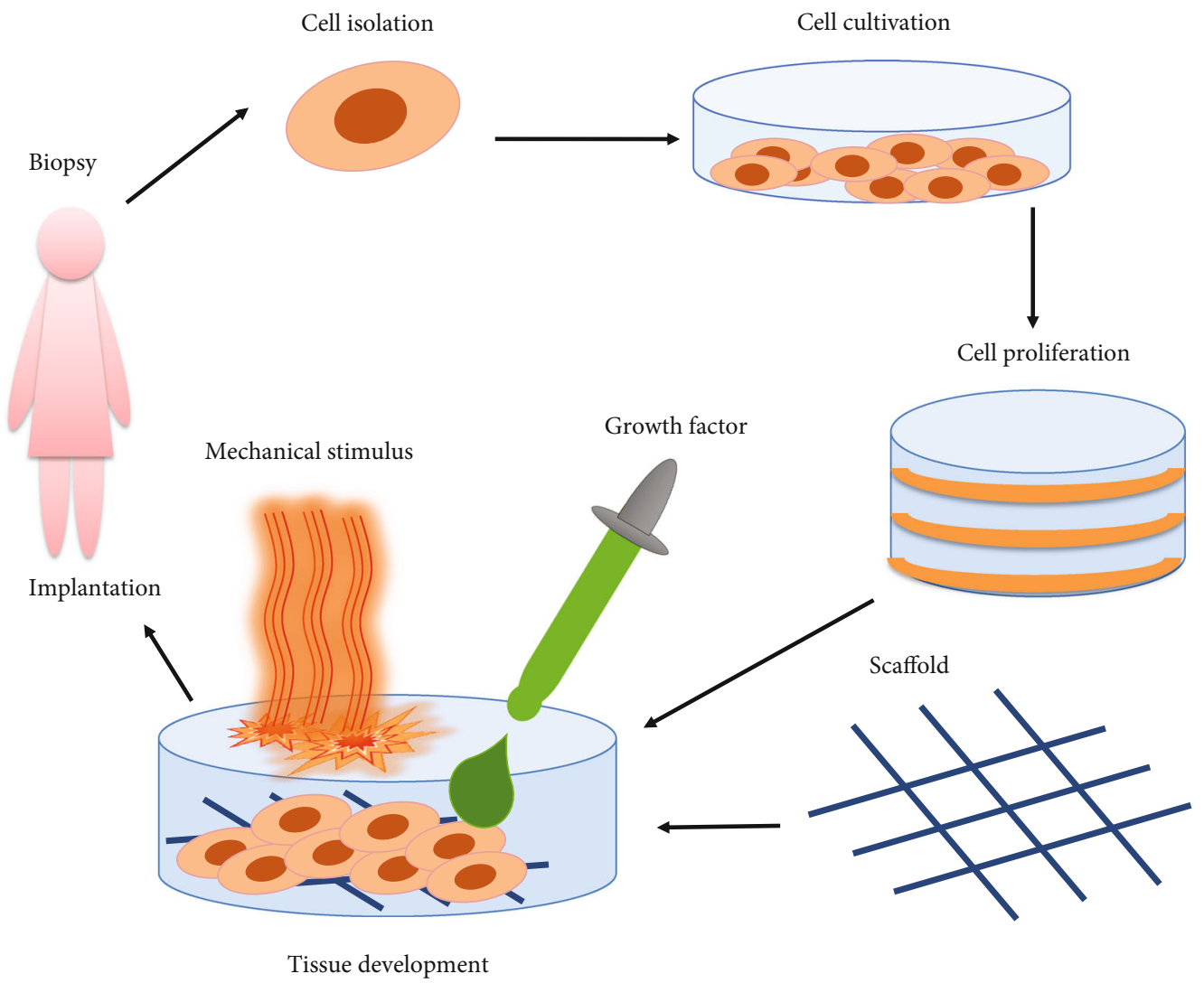

Figure 2: Regenerative medicine. The isolation of stem cells from the host through biopsy, which are encouraged to proliferate and differentiate using various growth factors and physical mechanisms. After differentiation, cells are transplanted back into the host.

used for BTE as the use of these cells entails no ethical conflict nor presents as a risk for immune rejection [60]. Scaffolds have been manufactured from a diverse assortment of materials such as bioceramics, biopolymers, metals, and composites [57]. These materials vary in factors like porosity architecture, mechanical ability, cell bondage, biocompatibility, cell proliferation, osteogenic differentiation ability, and mineralization, all of which influences the scaffold osteoconductivity and osteoinduction [57]. Additional studies established that osteogenesis is further enhanced by the combination of scaffolds and osteogenic growth factors such as fibroblast growth factor (FGF), insulin-like growth factor (IGF), epidermal growth factor (EPG), and bone morphogenic protein (BMP) which encourage bone manipulability [59].

2.6. Stem Cell Regenerative Therapy. Stem cells are deemed as a significantly unique tool for regenerative medicine because of their self-renewal and multidifferential characteristics [4]. The ability of cells to abundantly divide while preserving their undifferentiated state is called self-renewal [61]. This ensures that stem cells are increased during development; during adulthood, the cell numbers remain constant and posttrauma, these cell numbers are brought back to the normal amount $[61,62]$. Stem cells do not self-renew to a large extent when under physiological states, but when cell injury calls for regeneration, then stem cell potentials alter depending on the environment of these physiological changes [62]. The potential of a stem cell to differentiate into various types of cells is termed as potency [61]. The tissue from which stem cells are extracted will determine their potency because this changes the differentiation potential [4]. Stem cells are grouped according to their differentiation potentials as totipotent stem cells that form when a sperm fertilizes an oocyte to produce a zygote, possessing the ability to differentiate into embryonic and extraembryonic cell types [63]; pluripotent stem cells differentiate into the three germ layers: the endoderm, the mesoderm, and the ectoderm; examples of these cells are embryonic stem cells (ESCs) and induced pluripotent stem cells (iPSCs) [64]; multipotent stem cells produce various specialized cells of a particular lineage [65], and unipotent cells can only differentiate into one cell type but are able to self-renew [61]. Stem cells are divided into the following types: ESCs, iPSCs, tissue-specific progenitor stem cells (TSPSCs), umbilical cord stem cells (UCSCs), and MSCs [66]. ESCs yield large cell amounts through indefinite division and differentiate into multiple types of cells $[63,67]$. Despite these cells being an ideal regenerative cell type, the use of these cells come with immense ethical concerns because their isolation requires the destruction of embryos during their blastocyst-stage [68]. iPSCs are appealing cells because they are made from the cells of the patient which overcomes ethical challenges as well as cell transplant rejections $[69,70]$. However, the differences between ESCs and iPSCs remain unclear as differences in gene expression, DNA methylation, and donor cell epigenetic memories are because of induction and culture condition variations [64]. 
TSPSCs are not a preferred cell source because their cell population amount to the total population of cells is insufficient, therefore, rendering them unsatisfactory for harvesting [71]. UCSCs originate from the umbilical cord, which is rich in HSCs and MSCs, and make an ideal cell source because they are obtained noninvasively and unlike ESCs; their use has minimal ethical conflicts [72]. MSCs are multilineage cells primarily located in the bone marrow $[73,74]$ highly capable of self-renewal, differentiation, and proliferation [36]. MSCs have the ability to differentiate into either osteogenic, adipogenic, or chondrogenic cell lineages, as well as differentiate into tenocytes, smooth muscle cells, and stromal cells [37].

MSCs further derive into two cell types. The first cell type is BMDMSCs located in the bone marrow and functions as osteogenic progenitors and regulators of the HSC niche [36]. However, their extraction process is extremely invasive and their proliferation and differentiation abilities are weaker in comparison to other cell types which makes them unlikely for selection as a cell source [75]. The second type is ADSCs; these cells are easily isolated from adipose tissue via a harmless lipoaspirate $[53,76]$ and provide an abundance of cells able to self-renew. ADSCs are able to differentiate into multiple cell types such as adipocytes, osteoblasts, chondrocytes, and smooth muscle cells [39].

2.7. Adipose-Derived Stem Cells. ADSCs prove to be a preferable cell source because of two significant qualities: these cells are easily sourced from adipose tissues preferably located at the hip and abdomen in abundant amounts $[39,77]$ and have no ethical concerns like those of ESCs because ADSCs are isolated from autologous fat [78]. Other advantageous qualities include antiapoptotic, immunomodulatory, anti-inflammatory, and antiscarring [79]. ADSCs are harvested in one of three ways: Coleman's technique [80], liposuction [81], and excision [80], all of which are less invasive than that of harvesting ESCs. The differentiation potentials of ADSCs do not change depending on the method used [39] although, as with any invasive procedure, there lie associated risks such as bleeding, infection, necrosis, and injuries to nerves [36]. In comparison to BMDMSCs, ADSCs are more useful for the making of collagen than osteogenesis. Nonetheless, ADSCs are consistent for extended periods of time in culture, both morphologically and genetically, and as a result are better able to proliferate [82] and yield abundant amounts of cells during harvesting. Thus, ADSCs are selected as the preferable cell source [36]. Unfortunately, there is a lack of consensus regarding whether or not the age of the patient influences the ADSC properties; some studies state that both the quality and proliferation of the cells have no association with age [83] whereas others state that patients younger in age display increased osteogenic and angiogenic abilities and that older patients display lower differentiation and proliferation abilities [39].

2.8. Differentiation of ADSCs into Osteoblasts. To achieve successful differentiation of osteogenic lineages from ADMSCs in vitro, these cells need to be cultured in Dulbecco's Modified Eagle's Medium (DMEM) [84] with a combination of growth factors like ascorbic acid, $\beta$-glycerol phosphate, dexamethasone, and 1,25 vitamin D3 [85]. Additional factors like bone morphogenic protein 2 (BMP-2) further stimulate osteogenic differentiation of these cells [86]. Upon successful differentiation, the ADSCs exposed to these factors in culture will produce osteoblastic genes and proteins such as alkaline phosphatase, osteonectin, BMP-2, osteopontin, BMP-4, type 1 collagen, and Runx2 [87-89]. The successful osteogenic production from ADSCs indicates that these cells are capable of migration, proliferation, and differentiation should in vivo transplantation take place, therefore, promising the regeneration of the targeted bone tissue [90-92]. However, consistent success in all studies with the ADSC potential to differentiate into osteogenic lineages and proliferate still requires further investigation both in vitro and in vivo [93].

2.8.1. Biological Differentiation. A biological growth factor is a material that naturally occurs and is able to promote the proliferation and differentiation of a particular, desired cell type. In order for ADSC to differentiate into osteogenic cell lines, various biological growth factors such as insulin-like growth factor-1 (IGF-1), BMP-2, Wnt, basic fibroblast growth factor (bFGF), ascorbic acid, and 1,25 vitamin D3 [94] are added for the acceleration of proliferation, differentiation, and regulation of osteoblast cells as seen in Table 1: TGF- $\beta 1$, insulin, transferrin, dexamethasone, and ascorbic acid for chondrogenic differentiation; insulin, transferrin, and selenium for skeletal myogenic differentiation; and dexamethasone, ascorbic acid, and $\beta$-glycerophosphate for osteogenic differentiation. Therefore, the same MSC population in the mesoderm exposed to different extrinsic stimuli can initiate differentiation towards a specific cell type by triggering a tissue-specific transcription factor, such as SOX5/6/9 for chondrocytes and Runx2/Osterix for osteoblasts [95]. Significantly, some growth factors desirably inhibit the differentiation of ADSCs [96] such as epidermal growth factor (EFG) [97], platelet-derived growth factor (PDGF) [98], and vascular endothelial growth factor (VEGF) [99].

2.8.2. Chemical Differentiation. Chemical growth factors are used in addition to biological growth factors due to their regulatory capacity to ensure the expected fate of MSC differentiation [108]. Often, factors such as dexamethasone, calcium phosphate families, hypoxia-inducible factor, and betaglycerol phosphate (see Table 2) are added for osteogenic differentiation purposes and to prevent adipogenesis from taking place instead [85].

Although it has been established that certain growth factors, biological or chemical, have the potential to induce differentiation of ADSCs into osteoblast-like cells, it has also been noted that the control of osteogenesis and adipogenesis in ADSCs is closely related. ADSCs have a preferential commitment to adipogenic lineages unless specifically controlled [112]. This concern for control of lineage-specific differentiation using a combination of growth factors has prompted the use of combining mechanical stimulation for differentiation of ADSCs into osteoblasts. One such method is the use of PBM, where numerous studies, using either PBM therapy or in combination with biomaterials [113], have significantly sped up the synthesis of the bone matrix by increasing vascularization and decreasing inflammatory responses [114], 
TABLE 1: Biological growth factors introduced to ADSCs for osteogenic differentiation.

\begin{tabular}{|c|c|c|}
\hline $\begin{array}{l}\text { Biological growth } \\
\text { factors }\end{array}$ & Outcome of growth factors & Refs \\
\hline $\begin{array}{l}\text { Insulin-like growth } \\
\text { factor } 1 / 2\end{array}$ & $\begin{array}{l}\text { Stimulate both proliferation and terminal differentiation of MSCs, fine-tuning transcription factor } \\
\text { expression levels and activity, and defining commitment towards specific lineages from the three germ } \\
\text { layers. Overall, IGF-1 and IGF-2 play a significant role in MSC osteogenic differentiation and bone health. }\end{array}$ & $\begin{array}{l}{[95,} \\
100]\end{array}$ \\
\hline IGF-1 & $\begin{array}{l}\text { IGF-1 expression in MSCs enhances their proliferation with lower apoptosis; overexpression of IGF-1 in } \\
\text { osteoblasts can accelerate the rate of bone formation and increase the pace of matrix mineralization, IGF- } \\
\text { 1-transfected human MSCs were able to upregulate expression of various osteoblast genes. } 100 \mathrm{ng} / \mathrm{mL} \text { of } \\
\text { IGF-1 promotes differentiation into osteoblast-like cells. }\end{array}$ & $\begin{array}{c}{[101-} \\
104]\end{array}$ \\
\hline IGF-2 & IGF-2 appears to be more prominent than IGF-1 in promoting MSC self-renewal. & [100] \\
\hline BMP-2 & Accelerates proliferation and differentiation of osteoblast cells. & [105] \\
\hline Wnt3a & $\begin{array}{l}\text { Increased cell numbers and expanded the pool of MSCs capable of colony-forming unit- (CFU-) fibroblast } \\
\text { (CFU-F) and CFU- osteoblast (CFU-O); regulates osteoblast differentiation and maturation. }\end{array}$ & [106] \\
\hline Wnt5a & Maintained cell numbers and CFU-F and CFU-O numbers and increased the number of CFU-O. & [106] \\
\hline bFGF & $\begin{array}{l}\text { bFGF was shown to be required in maintaining stemness and proliferation. } \\
\text { Enhances the development of osteogenic cells. }\end{array}$ & $\begin{array}{l}{[94,} \\
107]\end{array}$ \\
\hline Ascorbic acid & Proliferates differentiated osteoblasts and inhibition of ADSC differentiation. & $\begin{array}{l}{[96-} \\
99]\end{array}$ \\
\hline $\begin{array}{l}1,25 \text { Di-hydroxy } \\
\text { vitamin D3 }\end{array}$ & Proliferates differentiated osteoblasts and inhibits ADSC differentiation. & $\begin{array}{c}{[96-} \\
99]\end{array}$ \\
\hline
\end{tabular}

TABLE 2: Chemical growth factors introduced to ADSCs for osteogenic differentiation.

\begin{tabular}{lcc}
\hline Chemical growth factors & Outcome of growth factors & Refs \\
\hline $\begin{array}{l}\text { Dexamethasone } \\
\text { Calcium phosphate }\end{array}$ & Proliferates differentiated osteoblasts and inhibits ADSC differentiation. & [85, 108, 109] \\
$\begin{array}{l}\text { Hypoxia-inducible factor } \\
\text { Beta-glycerol phosphate }\end{array}$ & Promotes the differentiation of osteogenic cell lines. & [110] \\
\hline
\end{tabular}

which raises the osteocyte populations as well as bFGF [115] along with promoting proliferation of cells [116].

2.8.3. Biophysical Differentiation. Within the SC microenvironment, MSCs are exposed to an assortment of biophysical cues. For example, hydrostatic pressure, fluid flow and accompanying shear stress, substrate strain and stiffness, substrate topography, and electromagnetic fields are all biophysical indicators responsible for cell membrane morphology changes and cell-matrix contacts and intracellular junction force generation producing intracellular stress [117]. The significance of biophysical prompts is identified to stimulate gene expression changes bringing about SC differentiation as identified with in vitro osteoblastic differentiation amongst BMSCs [118]. However, a recent study identified ADSCs for the purpose of osteogenic differentiation in the presence of prefabricated scaffolds, as a more feasible cell source than BMSCs and produced a successful bone regenerative outcome [119]. Studies have identified the use of mechanical stimulants like PBM to facilitate the proliferation and differentiation of various cell lines [120], and therefore, these might be a viable biophysical differentiation source to use for ADSC differentiation into osteogenic lineages.

2.9. Photobiomodulation. When light is used through coherent or incoherent light sources in a visible and near-infrared
(NIR) range, this is termed as PBM which stimulates endogenous chromophores bringing about both photochemical and photophysical reactions [120, 121]. Even though the process is still not fully comprehended, it is understood that cell signalling cascades, as well as effector molecules, are stimulated, promoting cell performance alterations [120, 122]. A commonly proposed biochemical reaction of $\mathrm{PBM}$ using wavelengths between 600 and $1100 \mathrm{~nm}$ is the "Cytochrome c Oxidase (CCO) Theory." This theorem is based on the penetration of red or NIR light through a cell's membrane, targeting its mitochondria and initiating light absorption by cytochrome c located within the mitochondria [123]. This enzymatic chromophore then aids in the electron transport chain during ATP production. An increase in ATP amounts tends to induce an increase in gene transcription within the cell nucleus bringing about an increase in DNA and RNA synthesis initiating cell proliferation [124]. .Currently, an ideal method to successfully increase proliferation and facilitate differentiation of stem cells through PBM is still being explored for clinical use $[116,125,126]$. The cellular mechanism variations caused by photochemical procedures, dependency of dose [127], cell line limitations for dosage [128], and the number of times as well as the period between each exposure [129] remain under investigation for the establishment of PBM parameters. However, the consensus amongst research is that $\mathrm{PBM}$ stimulates proliferation of cells when 
TABLE 3: Effects of PBM on ADSCs.

\begin{tabular}{|c|c|c|c|c|c|}
\hline $\begin{array}{l}\text { Wavelength } \\
(\mathrm{nm})\end{array}$ & $\begin{array}{l}\text { Output power } \\
\quad(\mathrm{mW})\end{array}$ & $\begin{array}{l}\text { Energy density } \\
\left(\mathrm{J} / \mathrm{cm}^{2}\right)\end{array}$ & $\begin{array}{l}\text { Irradiation } \\
\left(\mathrm{mW} / \mathrm{cm}^{2}\right)\end{array}$ & Effects & Refs \\
\hline 660 & 30 & 0.2 & 1.07 & The viability of cells was increased. & [137] \\
\hline 650 & 523 & $2,4,8$ & 6.67 & The $4 \mathrm{~J} / \mathrm{cm}^{2}$ enhanced ADSC proliferation. & [138] \\
\hline 680 & 3 and 4.5 & - & - & Migration was sped up. & [134] \\
\hline 808 & 200 & 3 & 0.2 & Proliferation was sped up. & [135] \\
\hline 636 & 85 & 5 & 9.3 & Both the cell viability and proliferation were increased. & [139] \\
\hline 825 & - & $5,10,15,20$ & - & $\begin{array}{l}\text { ADSC biphasic dose response occurred with fluences } 15 \text { and } \\
\qquad 20 \mathrm{~J} / \mathrm{cm}^{2}\end{array}$ & [132] \\
\hline $660 \pm 20$ & - & 6 & 10 & An increase in angiogenic factors and decreased apoptosis. & [133] \\
\hline 660 & 30 & $0.5,1.0$ & - & $\begin{array}{c}\text { Increased cellular growth and proliferation as well as VEGF, HGF, } \\
\text { and FGF growth factor secretion. }\end{array}$ & [136] \\
\hline
\end{tabular}

using a wavelength of/between 660 and $850 \mathrm{~nm}$ and fluence of/between 5 and $10 \mathrm{~J} / \mathrm{cm}^{2}$ [130]. Additionally, green light PBM ranging from $495 \mathrm{~nm}$ to $570 \mathrm{~nm}$ has been identified to better improve cell differentiation; however, the biochemical mechanism of this wavelength and further successful differentiation ability remain under investigation $[116,125,126]$. Notably, green light is anticipated to increase intracellular ROS in succinct amounts during the use of a low fluency which has demonstrated enhanced involvement in cell differentiation [125]. However, studies which used high fluences, greater than $10 \mathrm{~J} / \mathrm{cm}^{2}$, identified a biphasic dose response which expressed significantly increased ROS levels, cell damage, and cell death [131].

2.10. Effects of PBM on ADSCs. According to treatment responses, ADSCs when irradiated at a wavelength of $825 \mathrm{~nm}$ with fluences ranging between 5 and $15 \mathrm{~J} / \mathrm{cm}^{2}$ are stimulated but will often be inhibited by the use of a higher fluence of $20 \mathrm{~J} / \mathrm{cm}^{2}$ [132]. A study using a low-power laser with the parameters of $660 \mathrm{~nm} \pm 20 \mathrm{~nm}, 6 \mathrm{~J} / \mathrm{cm}^{2}$, and $10 \mathrm{mV} / \mathrm{cm}^{2}$ on ADSCs increases angiogenic factors and decreases apoptosis occurrence [133]. Another study using a low-power laser with the parameters of a wavelength of $660 \mathrm{~nm}+20 \mathrm{~nm}, 220 \mathrm{~V}+22 \mathrm{~V}$, and $50 \mathrm{~Hz}$ regulates the adhesion of cells and their migration signals by increasing EKK1/2 and FAK thus increasing overall cell migration. An increase in the proliferation, viability, and growth factors, particularly hepatocyte growth factor (HGF) and PDGF, was demonstrated in this study [134]. A study that used a low-power laser of $808 \mathrm{~nm}, 3 \mathrm{~J} / \mathrm{cm}^{2}$, and $0.2 \mathrm{~W} / \mathrm{cm}^{2}$ showed both an increase in cell proliferation and viability [135]. Significantly, a low-power laser of $660 \mathrm{~nm}$ and 0.5 and $1 \mathrm{~J} / \mathrm{cm}^{2}$ with dose dependency affects ADSCs and BMDMSCs by increasing both cellular growth and proliferation without making nuclear modifications and secretes growth factors VEGF, HGF, and FGF [136]. The studies of significantly producible results have been summarized in Table 3 .

2.11. Combined Effects of PBM and Differentiation Inducers on ADSCs. The combination of PBM, specifically green light, red light, and NIR wavelengths, with the addition of multiple growth factors, is believed to facilitate both cellular activity regulation and the differentiation of ADSCs [140]. The potential stimulation and inhibition consequences of PBM have on ADSCs tend to be wavelength and fluency factor dependent [120]. There have been numerous studies performed using various $\mathrm{PBM}$ parameters in combination with ADSC differentiation inducers such as dexamethasone, ascorbic acid, betaglycerophosphate, L-glutamine, and ascorbate-2-phosphate; a few examples of these studies are as follows (see Table 4). A study differentiating ADSCs into osteoblasts using various wavelengths but the same $3 \mathrm{~J} / \mathrm{cm}^{2}$ dose five times every second day established osteoblast differentiation stimulation to be successful with $420 \mathrm{~nm}$ and $540 \mathrm{~nm}$ wavelengths [125]. Another study that used MSCs at a wavelength of $635 \mathrm{~nm}$ had no change in cell viability but a wavelength of $808 \mathrm{~nm}$ increased the deposits of calcium thus impacting osteogenic differentiation [141]. The differentiation of ADSCs into osteogenic cell lines was also seen to be enhanced by the use of NIR laser light [142]. Another report stated that ADSCs were proliferated and differentiated by PBM at a red of $660 \mathrm{~nm}$ and a NIR of $810 \mathrm{~nm}$ wavelengths and it is understood that mitochondrial activity as well as the production of ATP is stimulated by PBM at this particular NIR wavelength [143]. Despite the majority of studies displaying positive photobiostimulatory outcomes when regenerating bone using low-level laser therapy, standardized parameters are yet to be established for reproducible results [130].

2.12. Current and Future Challenges. The current rise in global concern for osteoporosis as well as the risky, longterm treatment solutions for this disease has sparked the search and development of an efficient and minimally harmful long-term treatment [144]. The promising branch of regenerative medicine, SC therapy, is the emerging, probable solution to this increasing concern [53]. The principle of regenerative medicine is based on the healing of injured tissue via cell usage and combinations of various biological and/or chemical growth factors to restore cell structure, cell functionality, and create newly formed repaired tissues [145]. SC therapy is the rising star of regenerative medicine as SCs are uniquely able to infinitely self-renew and possess a multipotent ability into ESCs, iPSCs, TSPSCs, UCSCs, or MSCs cell types, where each cell type provides its own 
TABLE 4: The combined effects of using PBM and differentiation inducers for MSCs into osteoblasts.

\begin{tabular}{lcccc}
\hline Differentiation inducers & $\begin{array}{c}\text { Laser parameters } \\
\text { Wavelength } \\
(\mathrm{nm})\end{array}$ & $\begin{array}{c}\text { Fluency } \\
\left(\mathrm{J} / \mathrm{cm}^{2}\right)\end{array}$ & Effects \\
\hline $\begin{array}{l}\text { Dexamethasone, ascorbic acid, beta- } \\
\text { glycerophosphate }\end{array}$ & 420,540 & 3 & $\begin{array}{c}\text { Increased the concentration of intracellular calcium thus } \\
\text { increased osteogenic relative gene expression. } \\
\text { [ncreased the focal adhesion-localized vinculin which } \\
\text { promotes osteogenic differentiation. }\end{array}$ \\
$\begin{array}{l}\text { Dexamethasone, ascorbic acid, beta- } \\
\text { glycerophosphate, L-glutamine }\end{array}$ & 635,808 & 0.4 & $\begin{array}{c}\text { Osteogenic differentiation was encouraged. } \\
\begin{array}{l}\text { Dexamethasone, beta-glycerol phosphate, } \\
\text { ascorbate-2-phosphate }\end{array}\end{array}$ \\
$\begin{array}{l}\text { Dexamethasone, ascorbic acid, beta- } \\
\text { glycerophosphate }\end{array}$ & 809 & $0.5,1,2$ & Mineralization occurred which indicated cell differentiation. [142] \\
\hline
\end{tabular}

benefits and limitations [66]. ADSCs are obtained from a minimally invasive harvest and hold a large cell yield [5, 78]. The nonethically conflicting ADSCs significantly possess the ability to differentiate into adipocyte, osteoblast, and chondrocyte cell lineages [39]. According to studies, the differentiation of ADSCs into a specific cell lineage requires the influence of various growth factor combinations [146]. Successful in vitro ADSC differentiation into an osteogenic cell lineage has been accomplished by the unaccompanied use of PBM using biological and/or chemical growth factors such as ascorbic acid, $\beta$-glycerol phosphate, dexamethasone, 1,25 vitamin D3 [85], and BMP-2 [86] supplemented in an induction medium. The use of a specific concentration as well as the combination of these growth factors varies amongst studies and requires optimization for result reproducibility purposes along with functionality testing, as ADSCs have a tendency of favouring differentiation into adipogenic cell lineages unless purposely influenced into a different cell line [112]. PBM alone is understood to only be involved in biostimulation where an increase in cell proliferation and viability is noted when using red or NIR light [147]. Green PBM also has a biostimulatory effect causing an increase in intracellular ROS [125] aiding in the preparation of ADSC differentiation. However, it can therefore be said that the combined use of transducers and PBM on ADSCs for differentiating into osteogenic cell lineages could be a more effective technique than using these factors alone, where in vitro optimization and successful differentiation of ADSCs can be then studied in vivo. According to studies above, PBM at wavelengths ranging from $660 \mathrm{~nm}$ to $850 \mathrm{~nm}$ and fluences ranging between 5 and $15 \mathrm{~J} / \mathrm{cm}^{2}$ have facilitated ADSC differentiation into a desired cell lineage and enhanced proliferation [142]. Ideal ADSC differentiation into osteogenic cell lineage occurrence may be deduced from the above at wavelengths of either red light, green light, or NIR at a fluence below $15 \mathrm{~J} / \mathrm{cm}^{2}$. The use of green light wavelengths has been recognized to stimulate calcium ion channel exchange that leads to the increased expression of intracellular ROS in physiologically viable amounts which is understood to enhance cell differentiation [125]. The use of red light or NIR wavelengths has displayed efficient cytochrome c absorbance which enhances cell proliferation as well as cell viability and, when in the presence of differentiation transducers, facilitates the differentiation of cells $[110,126]$. A fluency that is greater than $10 \mathrm{~J} / \mathrm{cm}^{2}$ initiates biphasic dosing and ultimately causes cell death [131]; thus, fluences below $10 \mathrm{~J} / \mathrm{cm}^{2}$ are favorable. A power output below $100 \mathrm{~mW}$ will exclude the thermal effect [148] that can be introduced with light exposure omitting this external factor that might influence the cells negatively. The usage of these parameters will be best fitting for combining PBM with the use of differentiation growth factors to effectively enhance the differentiation of ADSCs into osteogenic cell lineages. The parameters of PBM such as the wavelength of the laser, the energy fluence, the number of times of exposure, and the period between each exposure [120] remain under current in vitro investigation for the establishment of optimal PBM parameters and a fixed protocol. The development of a fixed in vitro protocol for the use of ADSC differentiation into osteoblasts will produce a safe and sound procedure that may be efficiently translated in vivo for the clinical use of osteoporotic treatment and as a regenerative tool [130].

\section{Conclusion}

In conclusion, the use of various biological and chemical growth factors, in combination with a physical inducer, particularly PBM successfully proliferates and differentiates ADSCs into osteoblast cells. However, this procedure awaits the establishment of an ideal, set protocol of assured growth factors and PBM parameters as there are various published papers debating factors such as growth factors, wavelengths, and fluencies. The established protocol would ensure consecutive successful proliferation and differentiation for the specific ADSC cell lines into osteoblasts. Despite these inconsistencies, the use of PBM especially on this cell line for osteoblastic differentiation has been remarkable and remains promising to move forward in methodology, to achieve success in vitro, and possibly to achieve clinical studies as a possible form of treatment for osteoporosis.

\section{Data Availability}

The quantitative and qualitative data supporting this systematic review are from previously reported studies and datasets, 
which have been cited. These prior studies (and datasets) are cited at relevant places within the text as references.

\section{Conflicts of Interest}

The authors declare no conflict of interest.

\section{Acknowledgments}

The authors sincerely thank the University of Johannesburg and the Laser Research Centre for their facilities. This work is supported by the South African Research Chairs Initiative of the Department of Science and Technology and National Research Foundation of South Africa (SARChI/NRF-DST) (Grant No. 98337), received by Daniella Da Silva and Prof. Heidi Abrahamse. Dr. Anine Crous was supported by the National Research Foundation (NRF) S\&F-Scarce Skills Postdoctoral Fellowship (Grant No. 120752).

\section{References}

[1] I. Akkawi and H. Zmerly, "Osteoporosis: current concepts," Joints, vol. 6, no. 2, pp. 122-127, 2018.

[2] C. Li, G. Wei, Q. Gu, Q. Wang, S. Tao, and L. Xu, "Proliferation and differentiation of rat osteoporosis mesenchymal stem cells (MSCs) after telomerase reverse transcriptase (TERT) transfection," Medical Science Monitor, vol. 21, pp. 845-854, 2015.

[3] C. Mason and P. Dunnill, "A brief definition of regenerative medicine," Regenerative Medicine, vol. 3, no. 1, pp. 1-5, 2008.

[4] J. M. POLAK and A. E. Bishop, "Stem cells and tissue engineering: past, present, and future," Annals of the New York Academy of Sciences, vol. 1068, no. 1, pp. 352-366, 2006.

[5] A. Bajek, N. Gurtowska, J. Olkowska, L. Kazmierski, M. Maj, and T. Drewa, "Adipose-derived stem cells as a tool in cellbased therapies," Archivum Immunologiae et Therapiae Experimentalis (Warsz), vol. 64, no. 6, pp. 443-454, 2016.

[6] S. R. Tsai and M. R. Hamblin, "Biological effects and medical applications of infrared radiation," Journal of Photochemistry and Photobiology B: Biology, vol. 170, pp. 197-207, 2017.

[7] P. R. Arany, "Photobiomodulation therapy: communicating with stem cells for regeneration?," Photomedicine and Laser Surgery, vol. 34, no. 11, pp. 497-499, 2016.

[8] C. Cooper, G. Campion, and L. J. Melton, "Hip fractures in the elderly: a world-wide projection," Osteoporosis International, vol. 2, no. 6, pp. 285-289, 1992.

[9] O. Johnell and J. A. Kanis, "An estimate of the worldwide prevalence and disability associated with osteoporotic fractures," Osteoporosis International, vol. 17, no. 12, pp. 1726$1733,2006$.

[10] J. A. Kanis and J. A. Kanis, "Assessment of fracture risk and its application to screening for postmenopausal osteoporosis: synopsis of a WHO report," Osteoporosis International, vol. 4, no. 6, pp. 368-381, 1994.

[11] F. Cosman, S. J. de Beur, M. S. LeBoff et al., "Clinician’s guide to prevention and treatment of osteoporosis," Osteoporosis International, vol. 25, no. 10, pp. 2359-2381, 2014.

[12] E. F. Eriksen, "Treatment of osteopenia," Reviews in Endocrine \& Metabolic Disorders, vol. 13, no. 3, pp. 209-223, 2012.

[13] P. Coipeau, P. Rosset, A. Langonné et al., "Impaired differentiation potential of human trabecular bone mesenchymal stromal cells from elderly patients," Cytotherapy, vol. 11, no. 5, pp. 584-594, 2009.

[14] E. J. Moerman, K. Teng, D. A. Lipschitz, and B. Lecka-Czernik, "Aging activates adipogenic and suppresses osteogenic programs in mesenchymal marrow stroma/stem cells: the role of PPAR- $\gamma 2$ transcription factor and TGF- $\beta / \mathrm{BMP}$ signaling pathways," Aging Cell, vol. 3, no. 6, pp. 379-389, 2004.

[15] C. Li, P. Cheng, M. Liang et al., "MicroRNA-188 regulates age-related switch between osteoblast and adipocyte differentiation," The Journal of Clinical Investigation, vol. 125, no. 4, pp. 1509-1522, 2015.

[16] L. Liao, X. Yang, X. Su et al., "Redundant miR-3077-5p and miR-705 mediate the shift of mesenchymal stem cell lineage commitment to adipocyte in osteoporosis bone marrow," Cell Death \& Disease, vol. 4, no. 4, article e600, 2013.

[17] E. Hernlund, A. Svedbom, M. Ivergård et al., "Osteoporosis in the European Union: Medical management, epidemiology and economic burden: a report prepared in collaboration with the International Osteoporosis Foundation (IOF) and the European Federation of Pharmaceutical Industry Associations (EFPIA)," Archives of Osteoporosis, vol. 8, no. 1-2, p. 136, 2013.

[18] National Institutes of Health, "Osteoporosis prevention, diagnosis, and therapy," Journal of the American Medical Association, vol. 285, no. 6, pp. 785-795, 2001.

[19] W. B. Xia, S. L. He, L. Xu et al., "Rapidly increasing rates of hip fracture in Beijing, China," Journal of Bone and Mineral Research, vol. 27, no. 1, pp. 125-129, 2012.

[20] N. Yarom, R. Yahalom, Y. Shoshani, W. Hamed, E. Regev, and S. Elad, "Osteonecrosis of the jaw induced by orally administered bisphosphonates: incidence, clinical features, predisposing factors and treatment outcome," Osteoporosis International, vol. 18, no. 10, pp. 1363-1370, 2007.

[21] B. Abrahamsen, P. Eiken, and R. Eastell, "Subtrochanteric and diaphyseal femur fractures in patients treated with alendronate: a register-based national cohort study," Journal of Bone and Mineral Research, vol. 24, no. 6, pp. 1095-1102, 2009.

[22] E. M. Lewiecki, "Treatment of osteoporosis with denosumab," Maturitas, vol. 66, no. 2, pp. 182-186, 2010.

[23] B. Chaudhuri, "Key aspects of the mesenchymal stem cells (MSCs) in tissue engineering for in vitro skeletal muscle regeneration," Biotechnology and Molecular Biology Reviews, vol. 7, no. 1, pp. 5-15, 2012.

[24] K. Nemeth and E. Mezey, "Bone marrow stromal cells as immunomodulators. A primer for dermatologists," Journal of Dermatological Science, vol. 77, no. 1, pp. 11-20, 2015.

[25] M. Dave, K. Mehta, J. Luther, A. Baruah, A. B. Dietz, and W. A. Faubion, "Mesenchymal stem cell therapy for inflammatory bowel disease: a systematic review and meta-analysis," Inflammatory Bowel Diseases, vol. 21, no. 11, pp. 26962707, 2015.

[26] J. Liang, H. Zhang, B. Hua et al., “Allogenic mesenchymal stem cells transplantation in refractory systemic lupus erythematosus: a pilot clinical study," Annals of the Rheumatic Diseases, vol. 69, no. 8, pp. 1423-1429, 2010.

[27] F. Carrion, E. Nova, C. Ruiz et al., "Autologous mesenchymal stem cell treatment increased $T$ regulatory cells with no effect on disease activity in two systemic lupus erythematosus patients," Lupus, vol. 19, no. 3, pp. 317-322, 2009.

[28] P. Bianco and P. G. Robey, "Skeletal stem cells," Development, vol. 142, no. 6, pp. 1023-1027, 2015. 
[29] A. I. Caplan, "Mesenchymal stem cells: time to change the name!," Stem Cells Translational Medicine, vol. 6, no. 6, pp. 1445-1451, 2017.

[30] A. Friedenstein, R. Chailakhjan, and K. Lalykina, "The development of fibroblast colonies in monolayer cultures of guinea-pig bone marrow and spleen cells," Cell and Tissue Kinetics, vol. 3, no. 4, pp. 393-403, 1970.

[31] A. J. Friedenstein, R. K. Chailakhyan, N. V. Latsinik, A. F. Panasyuk, and I. V. Keiliss-Borok, "Stromal cells responsible for transferring the microenvironment of the hemopoietic tissues," Transplantation, vol. 17, no. 4, pp. 331-340, 1974.

[32] A. M. Rodriguez, C. Elabd, E. Z. Amri, G. Ailhaud, and C. Dani, "The human adipose tissue is a source of multipotent stem cells," Biochimie, vol. 87, no. 1, pp. 125-128, 2005.

[33] X. Liu, G. Kumagai, K. Wada et al., "High osteogenic potential of adipose-and muscle-derived mesenchymal stem cells in spinal-ossification model mice," Spine (Phila Pa 1976), vol. 42, no. 23, pp. E1342-E1349, 2017.

[34] R. Sarugaser, D. Lickorish, D. Baksh, M. M. Hosseini, and J. E. Davies, "Human umbilical cord perivascular (HUCPV) cells: a source of mesenchymal progenitors," Stem Cells, vol. 23, no. 2, pp. 220-229, 2005.

[35] S. Schneider, M. Unger, M. Van Griensven, and E. R. Balmayor, "Adipose-derived mesenchymal stem cells from liposuction and resected fat are feasible sources for regenerative medicine," European Journal of Medical Research, vol. 22, no. 1, p. 17, 2017.

[36] R. E. B. Fitzsimmons, M. S. Mazurek, A. Soos, and C. A. Simmons, "Mesenchymal stromal/stem cells in regenerative medicine and tissue engineering," Stem Cells International, vol. 2018, Article ID 8031718, 16 pages, 2018.

[37] K. C. Elahi, G. Klein, M. Avci-Adali, K. D. Sievert, S. Macneil, and W. K. Aicher, "Human mesenchymal stromal cells from different sources diverge in their expression of cell surface proteins and display distinct differentiation patterns," Stem Cells International, vol. 2016, Article ID 5646384, 9 pages, 2016.

[38] G. Spagnuolo, B. Codispoti, M. Marrelli, C. Rengo, S. Rengo, and M. Tatullo, "Commitment of oral-derived stem cells in dental and maxillofacial applications," Dental Journal, vol. 6, no. 4, pp. 72-78, 2018.

[39] R. Dai, Z. Wang, R. Samanipour, K. I. Koo, and K. Kim, “Adipose-derived stem cells for tissue engineering and regenerative medicine applications," Stem Cells International, vol. 2016, Article ID 6737345, 19 pages, 2016.

[40] A. Infante and C. I. Rodríguez, "Osteogenesis and aging: lessons from mesenchymal stem cells," Stem Cell Research \& Therapy, vol. 9, no. 1, p. 244, 2018.

[41] R. Eastell and P. Szulc, "Use of bone turnover markers in postmenopausal osteoporosis," The Lancet Diabetes and Endocrinology, vol. 5, no. 11, pp. 908-923, 2017.

[42] K. Yamamoto, T. Kishida, Y. Sato et al., "Direct conversion of human fibroblasts into functional osteoblasts by defined factors," Proceedings of the National Academy of Sciences of the United States of America, vol. 112, no. 19, pp. 6152-6157, 2015.

[43] I. Levinger, E. Seeman, G. Jerums et al., "Glucose-loading reduces bone remodeling in women and osteoblast function in vitro," Physiological Reports, vol. 4, no. 3, pp. e12700e12710, 2016.

[44] D. L. Chau, S. V. Edelman, and M. Chandran, "Osteoporosis and diabetes," Current Diabetes Reports, vol. 3, no. 1, pp. 3742, 2003.
[45] A. Neve, A. Corrado, and F. P. Cantatore, "Osteoblast physiology in normal and pathological conditions," Cell and Tissue Research, vol. 343, no. 2, pp. 289-302, 2011.

[46] G. Rawadi, B. Vayssière, F. Dunn, R. Baron, and S. RomanRoman, "BMP-2 controls alkaline phosphatase expression and osteoblast mineralization by a Wnt autocrine loop," Journal of Bone and Mineral Research, vol. 18, no. 10, pp. 1842 1853, 2003.

[47] P. J. Marie, "Bone cell-matrix protein interactions," Osteoporosis International, vol. 20, no. 6, pp. 1037-1042, 2009.

[48] J. B. Lian, G. S. Stein, A. J. van Wijnen et al., "MicroRNA control of bone formation and homeostasis," Nature Reviews. Endocrinology, vol. 8, no. 4, pp. 212-227, 2012.

[49] A. T. Shaw and E. M. Gravallese, "Mediators of inflammation and bone remodeling in rheumatic disease," Seminars in Cell \& Developmental Biology, vol. 49, pp. 2-10, 2016.

[50] N. A. Sims and T. J. Martin, "Coupling the activities of bone formation and resorption: a multitude of signals within the basic multicellular unit," BoneKEy Reports, vol. 3, pp. 1-10, 2014.

[51] J. P. Vacanti, J. B. Otte, and J. A. Wertheim, Introduction. Regenerative medicine and solid organ transplantation from a historical perspective, Elsevier Inc., 2014.

[52] P. Bajaj, R. M. Schweller, A. Khademhosseini, J. L. West, and R. Bashir, "3D biofabrication strategies for tissue engineering and regenerative medicine," Annual Review of Biomedical Engineering, vol. 16, no. 1, pp. 247-276, 2014.

[53] M. B. Fisher and R. L. Mauck, "Tissue engineering and regenerative medicine: Recent innovations and the transition to translation," Tissue Engineering-Part B Reviews, vol. 19, no. 1, pp. 1-13, 2013.

[54] D. J. Mooney and N. Huebsch, "Inspiration and application in the evolution of biomaterials," Nature, vol. 462, pp. 426432, 2009.

[55] A. K. Dewan, M. A. Gibson, J. H. Elisseeff, and M. E. Trice, "Evolution of autologous chondrocyte repair and comparison to other cartilage repair techniques," BioMed Research International, vol. 2014, Article ID 272481, 11 pages, 2014.

[56] T. O'Brien and F. P. Barry, "Stem cell therapy and regenerative medicine," Mayo Clinic Proceedings, vol. 84, no. 10, pp. 859-861, 2009.

[57] B. Stevens, Y. Yang, A. Mohandas, B. Stucker, and K. T. Nguyen, "A review of materials, fabrication methods, and strategies used to enhance bone regeneration in engineered bone tissues," Journal of Biomedical Materials Research Part B: Applied Biomaterials, vol. 85B, no. 2, pp. 573-582, 2008.

[58] T. Ghassemi, A. Shahroodi, M. H. Ebrahimzadeh, A. Mousavian, J. Movaffagh, and A. Moradi, "Current concepts in scaffolding for bone tissue engineering," Archives of Bone and Joint Surgery, vol. 6, no. 2, pp. 90-99, 2018.

[59] S. K. Nandi, S. Roy, P. Mukherjee, B. Kundu, D. K. De, and D. Basu, "Orthopaedic applications of bone graft \&amp; graft substitutes: a review," The Indian Journal of Medical Research, vol. 132, pp. 15-30, 2010.

[60] A. Shahdadfar, K. Frønsdal, T. Haug, F. P. Reinholt, and J. E. Brinchmann, "In vitro expansion of human mesenchymal stem cells: choice of serum is a determinant of cell proliferation, differentiation, gene expression, and transcriptome stability," Stem Cells, vol. 23, no. 9, pp. 1357-1366, 2005.

[61] L. Sekhar and N. Bisht, "Stem cell therapy," Apollo Medicine, vol. 3, no. 3, pp. 271-276, 2006. 
[62] H. Shenghui, D. Nakada, and S. J. Morrison, "Mechanisms of stem cell self-renewal," Annual Review of Cell and Developmental Biology, vol. 25, no. 1, pp. 377-406, 2009.

[63] S. Mitalipov and D. Wolf, "Totipotency, Pluripotency and Nuclear reprogramming," Advances in Biochemical Engineering/Biotechnology, vol. 114, pp. 185-199, 2009.

[64] S. Yamanaka, "Induced pluripotent stem cells: past, present, and future," Cell Stem Cell, vol. 10, no. 6, pp. 678-684, 2012.

[65] J. Dulak, K. Szade, A. Szade, W. Nowak, and A. Józkowicz, "Adult stem cells: hopes and hypes of regenerative medicine," Acta Biochimica Polonica, vol. 62, no. 3, pp. 329-337, 2015.

[66] R. S. Mahla, "Stem cells applications in regenerative medicine and disease therapeutics," International Journal of Cell Biology, vol. 2016, Article ID 6940283, 24 pages, 2016.

[67] D. Howard, L. D. Buttery, K. M. Shakesheff, and S. J. Roberts, "Tissue engineering: strategies, stem cells and scaffolds," Journal of Anatomy, vol. 213, no. 1, pp. 66-72, 2008.

[68] G. Keller, "Embryonic stem cell differentiation: emergence of a new era in biology and medicine," Genes \& Development, vol. 19, no. 10, pp. 1129-1155, 2005.

[69] K. Tanabe, K. Takahashi, and S. Yamanaka, "Induction of pluripotency by defined factors," Proceedings of the Japan Academy, Ser. B, Physical and Biological Sciences, vol. 90, no. 3, pp. 83-96, 2014.

[70] R. Araki, M. Uda, Y. Hoki et al., "Negligible immunogenicity of terminally differentiated cells derived from induced pluripotent or embryonic stem cells," Nature, vol. 494, no. 7435, pp. 100-104, 2013.

[71] S. Pennings, K. J. Liu, and H. Qian, "The stem cell niche: interactions between stem cells and their environment," Stem Cells International, vol. 2018, Article ID 4879379, 3 pages, 2018.

[72] S. Shahrokhi, F. Menaa, K. Alimoghaddam, C. McGuckin, and M. Ebtekar, "Insights and hopes in umbilical cord blood stem cell transplantations," Journal of Biomedicine \& Biotechnology, vol. 2012, Article ID 572821, 11 pages, 2012.

[73] M. Dominici, K. le Blanc, I. Mueller et al., "Minimal criteria for defining multipotent mesenchymal stromal cells. The International Society for Cellular Therapy position statement," Cytotherapy, vol. 8, no. 4, pp. 315-317, 2006.

[74] J. F. Stoltz, N. de Isla, Y. P. Li et al., "Stem Cells and regenerative medicine: myth or reality of the 21th century," Stem Cells International, vol. 2015, Article ID 734731, 19 pages, 2015.

[75] J. Yu, M. A. Vodyanik, K. Smuga-Otto et al., "Induced pluripotent stem cell lines derived from human somatic cells," Science, vol. 318, no. 5858, pp. 1917-1920, 2007.

[76] L. Frese, P. E. Dijkman, and S. P. Hoerstrup, "Adipose tissuederived stem cells in regenerative medicine," Transfusion Medicine and Hemotherapy, vol. 43, no. 4, pp. 268-274, 2016.

[77] P. C. Baer and H. Geiger, "Adipose-derived mesenchymal stromal/stem cells: tissue localization, characterization, and heterogeneity," Stem Cells International, vol. 2012, Article ID 812693, 11 pages, 2012.

[78] W. P. Cawthorn, E. L. Scheller, and O. A. MacDougald, “Adipose tissue stem cells: the great WAT hope," Trends in Endocrinology and Metabolism, vol. 23, no. 6, pp. 270-277, 2012.

[79] F. Bertolini, V. Lohsiriwat, J. Y. Petit, and M. G. Kolonin, "Adipose tissue cells, lipotransfer and cancer: a challenge for scientists, oncologists and surgeons," Biochimica et Bio- physica Acta, Reviews on Cancer, vol. 1826, no. 1, pp. 209214, 2012.

[80] T. Iyyanki, J. Hubenak, J. Liu, E. I. Chang, E. K. Beahm, and Q. Zhang, "Harvesting technique affects adipose-derived stem cell yield," Aesthetic Surgery Journal, vol. 35, no. 4, pp. 467-476, 2015.

[81] M. J. Oedayrajsingh-Varma, S. M. van Ham, M. Knippenberg et al., "Adipose tissue-derived mesenchymal stem cell yield and growth characteristics are affected by the tissueharvesting procedure," Cytotherapy, vol. 8, no. 2, pp. 166177, 2006.

[82] M. Strioga, S. Viswanathan, A. Darinskas, O. Slaby, and J. Michalek, "Same or not the same? comparison of adipose tissue-derived versus bone marrow-derived mesenchymal stem and stromal cells," Stem Cells and Development, vol. 21, no. 14, pp. 2724-2752, 2012.

[83] O. S. Beane, V. C. Fonseca, L. L. Cooper, G. Koren, and E. M. Darling, "Impact of aging on the regenerative properties of bone marrow-, muscle-, and adipose-derived mesenchymal stem/stromal cells," PLoS One, vol. 9, no. 12, p. e115963, 2014.

[84] H. K. Kim, J. H. Kim, A. A. Abbas et al., "Red light of 647 nm enhances osteogenic differentiation in mesenchymal stem cells," Lasers in Medical Science, vol. 24, no. 2, pp. 214-222, 2009.

[85] O. A. Trentz, D. Arikketh, V. Sentilnathan et al., "Surface proteins and osteoblast markers: characterization of human adipose tissue-derived osteogenic cells," European Journal of Trauma and Emergency Surgery, vol. 36, no. 5, pp. 457-463, 2010.

[86] S. J. Lee, S. W. Kang, H. J. Do et al., "Enhancement of bone regeneration by gene delivery of BMP2/Runx2 bicistronic vector into adipose-derived stromal cells," Biomaterials, vol. 31, no. 21, pp. 5652-5659, 2010.

[87] T. Rada, R. L. Reis, and M. E. Gomes, “Adipose tissue-derived stem cells and their application in bone and cartilage tissue engineering," Tissue Engineering-Part B Reviews, vol. 15, no. 2, pp. 113-125, 2009.

[88] Y. Zhao, H. Lin, J. Zhang et al., "Crosslinked threedimensional demineralized bone matrix for the adiposederived stromal cell proliferation and differentiation," Tissue Engineering. Part A, vol. 15, no. 1, pp. 13-21, 2009.

[89] J. H. Lee, J. W. Rhie, D. Y. Oh, and S. T. Ahn, "Osteogenic differentiation of human adipose tissue-derived stromal cells (hASCs) in a porous three-dimensional scaffold," Biochemical and Biophysical Research Communications, vol. 370, no. 3, pp. 456-460, 2008.

[90] O. Jeon, J. W. Rhie, I. K. Kwon, J. H. Kim, B. S. Kim, and S. H. Lee, "In vivo bone formation following transplantation of human adipose-derived stromal cells that are not differentiated osteogenically," Tissue Engineering Parts A, vol. 14, no. 8, pp. 1285-1294, 2008.

[91] Y. Lin, T. Wang, L. Wu et al., "Ectopic andin situ bone formation of adipose tissue-derived stromal cells in biphasic calcium phosphate nanocomposite," Journal of Biomedial Materials Research Part A, vol. 81A, no. 4, pp. 900-910, 2007.

[92] X. Li, J. Yao, L. Wu et al., "Osteogenic induction of adiposederived stromal cells: not a requirement for bone formation in vivo," Artificial Organs, vol. 34, no. 1, pp. 46-54, 2010.

[93] B. E. Grottkau and Y. Lin, "Osteogenesis of adipose-derived stem cells," Bone Research, vol. 1, no. 2, pp. 133-145, 2013. 
[94] T. Ito, R. Sawada, Y. Fujiwara, and T. Tsuchiya, "FGF-2 increases osteogenic and chondrogenic differentiation potentials of human mesenchymal stem cells by inactivation of TGF- $\beta$ signaling," Cytotechnology, vol. 56, no. 1, pp. 1-7, 2008.

[95] T. Katagiri and N. Takahashi, "Regulatory mechanisms of osteoblast and osteoclast differentiation," Oral Diseases, vol. 8, no. 3, pp. 147-159, 2002.

[96] Y. Ji, P. Zhang, Y. Xing et al., "Effect of $1 \alpha, 25-$ dihydroxyvitamin D3 on the osteogenic differentiation of human periodontal ligament stem cells and the underlying regulatory mechanism," International Journal of Molecular Medicine, vol. 43, pp. 167-176, 2018.

[97] S. Y. Song, H. M. Chung, and J. H. Sung, "The pivotal role of VEGF in adipose-derived-stem-cell-mediated regeneration," Expert Opinion on Biological Therapy, vol. 10, no. 11, pp. 1529-1537, 2010.

[98] H. Y. Liu, A. T. H. Wu, C. Y. Tsai et al., "The balance between adipogenesis and osteogenesis in bone regeneration by platelet-rich plasma for age-related osteoporosis," Biomaterials, vol. 32, no. 28, pp. 6773-6780, 2011.

[99] V. Cervelli, M. G. Scioli, P. Gentile et al., "Platelet-rich plasma greatly potentiates insulin-induced adipogenic differentiation of human adipose-derived stem cells through a serine/threonine kinase Akt-dependent mechanism and promotes clinical fat graft maintenance," Stem Cells Translational Medicine, vol. 1, no. 3, pp. 206-220, 2012.

[100] A. Youssef, D. Aboalola, and V. K. M. Han, "The roles of insulin-like growth factors in mesenchymal stem cell niche," Stem Cells International, vol. 2017, Article ID 9453108, 12 pages, 2017.

[101] C. Hu, Y. Wu, Y. Wan, Q. Wang, and J. Song, "Introduction of hIGF-1 gene into bone marrow stromal cells and its effects on the cell's biological behaviors," Cell Transplantation, vol. 17, no. 9, pp. 1067-1081, 2008.

[102] T. L. Clemens and S. D. Chernausek, "Genetic strategies for elucidating insulin-like growth factor action in bone," Growth Hormone \& IGF Research, vol. 14, no. 3, pp. 195199, 2004.

[103] H. Koch, J. A. Jadlowiec, and P. G. Campbell, "Insulin-like growth factor-I induces early osteoblast gene expression in human mesenchymal stem cells," Stem Cells and Development, vol. 14, no. 6, pp. 621-631, 2005.

[104] X. Feng, D. Huang, X. Lu et al., "Insulin-like growth factor 1 can promote proliferation and osteogenic differentiation of human dental pulp stem cells via mTOR pathway," Development, Growth \& Differentiation, vol. 56, no. 9, pp. 615-624, 2014.

[105] L. Hu, C. Yin, F. Zhao, A. Ali, J. Ma, and A. Qian, "Mesenchymal stem cells: cell fate decision to osteoblast or adipocyte and application in osteoporosis treatment," International Journal of Molecular Sciences, vol. 19, no. 2, p. 360, 2018.

[106] D. Baksh and R. S. Tuan, "Canonical and non-canonical wnts differentially affect the development potential of primary isolate of human bone marrow mesenchymal stem cells," Journal of Cellular Physiology, vol. 212, no. 3, pp. 817-826, 2007.

[107] M. H. Stewart, S. C. Bendall, and M. Bhatia, "Deconstructing human embryonic stem cell cultures: niche regulation of selfrenewal and pluripotency," Journal of Molecular Medicine, vol. 86, no. 8, pp. 875-886, 2008.

[108] Z. J. Liu, Y. Zhuge, and O. C. Velazquez, "Trafficking and differentiation of mesenchymal stem cells," Journal of Cellular Biochemistry, vol. 106, no. 6, pp. 984-991, 2009.
[109] F. Langenbach and J. Handschel, "Effects of dexamethasone, ascorbic acid and ?-glycerophosphate on the osteogenic differentiation of stem cells in vitro," Stem Cell Research \& Therapy, vol. 4, no. 5, p. 117, 2013.

[110] P. Müller, U. Bulnheim, A. Diener et al., "Calcium phosphate surfaces promote osteogenic differentiation of mesenchymal stem cells," Journal of Cellular and Molecular Medicine, vol. 12, no. 1, pp. 281-291, 2008.

[111] C. Merceron, K. Ranganathan, E. Wang et al., "Hypoxiainducible factor $2 \alpha$ is a negative regulator of osteoblastogenesis and bone mass accrual," Bone Research, vol. 7, no. 1, p. 7, 2019.

[112] S. Y. Lee, J. H. Lee, J. Y. Kim, Y. C. Bae, K. T. Suh, and J. S. Jung, "BMP2 increases adipogenic differentiation in the presence of dexamethasone, which is inhibited by the treatment of TNF- $\alpha$ in human adipose tissue-derived stromal cells," Cellular Physiology and Biochemistry, vol. 34, no. 4, pp. 1339-1350, 2014.

[113] U. K. Akyol, S. Sipal, E. Demirci, and M. Gungormus, "The influence of low-level laser therapy with alendronate irrigation on healing of bone defects in rats," Lasers in Medical Science, vol. 30, no. 3, pp. 1141-1146, 2015.

[114] A. Pinheiro and M. Gerbi, "Photo-engineering of bone repair processes," Photomedicine and Laser Surgery, vol. 24, no. 2, pp. 169-178, 2006.

[115] I. Saygun, S. Karacay, M. Serdar, A. U. Ural, M. Sencimen, and B. Kurtis, "Effects of laser irradiation on the release of basic fibroblast growth factor (bFGF), insulin like growth factor-1 (IGF-1), and receptor of IGF-1 (IGFBP3) from gingival fibroblasts," Lasers in Medical Science, vol. 23, no. 2, pp. 211-215, 2008.

[116] A. L. M. de Andrade, G. F. Luna, P. Brassolatti et al., "Photobiomodulation effect on the proliferation of adipose tissue mesenchymal stem cells," Lasers in Medical Science, vol. 34, no. 4, pp. 677-683, 2019.

[117] F. M. Pavalko, S. M. Norvell, D. B. Burr, C. H. Turner, R. L. Duncan, and J. P. Bidwell, "A model for mechanotransduction in bone cells: the load-bearing mechanosomes," Journal of Cellular Biochemistry, vol. 88, no. 1, pp. 104-112, 2003.

[118] P. M. Govey, A. E. Loiselle, and H. J. Donahue, "Biophysical regulation of stem cell differentiation," Current Osteoporosis Reports, vol. 11, no. 2, pp. 83-91, 2013.

[119] H. Semyari, M. Rajipour, S. Sabetkish, N. Sabetkish, F. M. Abbas, and A. M. Kajbafzadeh, "Evaluating the bone regeneration in calvarial defect using osteoblasts differentiated from adipose-derived mesenchymal stem cells on three different scaffolds: an animal study," Cell and Tissue Banking, vol. 17, no. 1, pp. 69-83, 2016.

[120] L. F. De Freitas and M. R. Hamblin, "Proposed mechanisms of photobiomodulation or low-level light therapy," IEEE Journal of Selected Topics in Quantum Electronics, vol. 22, no. 3, pp. 348-364, 2016.

[121] J. J. Anders, P. R. Arany, G. D. Baxter, and R. J. Lanzafame, "Light-emitting diode therapy and low-level light therapy are photobiomodulation therapy," Photobiomodulation, Photomedicine, and Laser Surgery, vol. 37, no. 2, pp. 63-65, 2019.

[122] H. Chung, T. Dai, S. K. Sharma, Y.-Y. Huang, J. D. Carroll, and M. R. Hamblin, "The nuts and bolts of low-level laser (light) therapy," Annals of Biomedical Engineering, vol. 40, no. 2, pp. 516-533, 2012. 
[123] A. P. Sommer, "Mitochondrial cytochrome c oxidase is not the primary acceptor for near infrared light-it is mitochondrial bound water: the principles of low-level light therapy," Annals of Translational Medicine, vol. 7, no. S1, p. S13, 2019.

[124] H. Serrage, V. Heiskanen, W. M. Palin et al., "Under the spotlight: mechanisms of photobiomodulation concentrating on blue and green light," Photochemical \& Photobiological Sciences, vol. 18, no. 8, pp. 1877-1909, 2019.

[125] Y. Wang, Y. Y. Huang, Y. Wang, P. Lyu, and M. R. Hamblin, "Photobiomodulation (blue and green light) encourages osteoblastic- differentiation of human adipose-derived stem cells: role of intracellular calcium and light-gated ion channels," Scientific Reports, vol. 6, no. 1, pp. 1-9, 2016.

[126] A. M. Deana, A. M. de Souza, V. P. Teixeira, R. A. MesquitaFerrari, S. K. Bussadori, and K. P. S. Fernandes, "The impact of photobiomodulation on osteoblast-like cell: a review," Lasers in Medical Science, vol. 33, no. 5, pp. 1147-1158, 2018.

[127] M. Soleimani, E. Abbasnia, M. Fathi, H. Sahraei, Y. Fathi, and G. Kaka, "The effects of low-level laser irradiation on differentiation and proliferation of human bone marrow mesenchymal stem cells into neurons and osteoblasts-an in vitro study," Lasers in Medical Science, vol. 27, no. 2, pp. 423430, 2012.

[128] T. S. de Oliveira, A. J. Serra, M. T. Manchini et al., "Effects of low level laser therapy on attachment, proliferation, and gene expression of VEGF and VEGF receptor 2 of adipocytederived mesenchymal stem cells cultivated under nutritional deficiency," Lasers in Medical Science, vol. 30, no. 1, pp. 217-223, 2015.

[129] D. Hawkins and H. Abrahamse, "Effect of multiple exposures of low-level laser therapy on the cellular responses of wounded human skin fibroblasts," Photomedicine and Laser Surgery, vol. 24, no. 6, pp. 705-714, 2006.

[130] J. S. B. Escudero, M. G. B. Perez, M. P. de Oliveira Rosso et al., "Photobiomodulation therapy (PBMT) in bone repair: a systematic review," Injury, vol. 50, no. 11, pp. 1853-1867, 2019.

[131] M. Bayat, F. Javadieh, and M. Dadpay, "Effect of He-Ne laser radiation on healing of osteochondral defect in rabbit: a histological study," Journal of Rehabilitation Research and Development, vol. 46, no. 9, pp. 1135-1142, 2009.

[132] R. Ebrahimpour-Malekshah, A. Amini, F. Zare et al., "Combined therapy of photobiomodulation and adipose-derived stem cells synergistically improve healing in an ischemic, infected and delayed healing wound model in rats with type 1 diabetes mellitus," BMJ Open Diabetes Research \& Care, vol. 8, no. 1, p. e001033, 2020.

[133] I. S. Park, P. S. Chung, J. C. Ahn, and A. Leproux, "Human adipose-derived stem cell spheroid treated with photobiomodulation irradiation accelerates tissue regeneration in mouse model of skin flap ischemia," Lasers in Medical Science, vol. 32, no. 8, pp. 1737-1746, 2017.

[134] K. Yin, R. Zhu, S. Wang, and R. C. Zhao, "Low-level laser effect on proliferation, migration, and antiapoptosis of mesenchymal stem cells," Stem Cells and Development, vol. 26, no. 10, pp. 762-775, 2017.

[135] J. Nurković, I. Zaletel, S. Nurković et al., "Combined effects of electromagnetic field and low-level laser increase proliferation and alter the morphology of human adipose tissuederived mesenchymal stem cells," Lasers in Medical Science, vol. 32, no. 1, pp. 151-160, 2017.

[136] C. A. Barboza, F. Ginani, D. M. Soares, Á. C. G. Henriques, and R. A. Freitas, "Low-level laser irradiation induces in vitro proliferation of mesenchymal stem cells," Einstein (Sao Paulo), vol. 12, no. 1, pp. 75-81, 2014.

[137] R. N. de Lima, S. S. Vieira, E. L. Antonio et al., "Low-level laser therapy alleviates the deleterious effect of doxorubicin on rat adipose tissue-derived mesenchymal stem cells," Journal of Photochemistry and Photobiology B: Biology, vol. 196, article 111512, 2019.

[138] X. Liao, S. H. Li, G. H. Xie et al., "Preconditioning with lowlevel laser irradiation enhances the therapeutic potential of human adipose-derived stem cells in a mouse model of photoaged skin," Photochemistry and Photobiology, vol. 94, no. 4, pp. 780-790, 2018.

[139] B. Mvula and H. Abrahamse, "Differentiation potential of adipose-derived stem cells when cocultured with smooth muscle cells, and the role of low-intensity laser irradiation," Photomedicine and Laser Surgery, vol. 34, no. 11, pp. 509$515,2016$.

[140] S. George, M. R. Hamblin, and H. Abrahamse, "Current and future trends in adipose stem cell differentiation into neuroglia," Photomedicine and Laser Surgery, vol. 36, no. 5, pp. 230-240, 2018.

[141] A. Tani, F. Chellini, M. Giannelli, D. Nosi, S. Zecchi-Orlandini, and C. Sassoli, "Red $(635 \mathrm{~nm})$, near-infrared $(808 \mathrm{~nm})$ and violet-blue $(405 \mathrm{~nm})$ photobiomodulation potentiality on human osteoblasts and mesenchymal stromal cells: a morphological and molecular in vitro study," International Journal of Molecular Sciences, vol. 19, no. 7, p. 1946, 2018.

[142] G. Bölükbaşı Ateş, A. Ak, B. Garipcan, and M. Gülsoy, "Photobiomodulation effects on osteogenic differentiation of adipose-derived stem cells," Cytotechnology, vol. 72, no. 2, pp. 247-258, 2020.

[143] Y. Wang, Y. Y. Huang, Y. Wang, P. Lyu, and M. R. Hamblin, "Photobiomodulation of human adipose-derived stem cells using $810 \mathrm{~nm}$ and $980 \mathrm{~nm}$ lasers operates via different mechanisms of action," Biochimica et Biophysica Acta, vol. 1861, no. 2, pp. 441-449, 2017.

[144] C. Cheng, K. Wentworth, and D. M. Shoback, "New frontiers in osteoporosis therapy," Annual Review of Medicine, vol. 71, no. 1, pp. 277-288, 2020.

[145] A. S. Mao and D. J. Mooney, "Regenerative medicine: current therapies and future directions," Proceedings of the National Academy of Sciences of the United States of America, vol. 112, no. 47, pp. 14452-14459, 2015.

[146] Y. Açil, A. A. Ghoniem, J. Wiltfang, and M. Gierloff, "Optimizing the osteogenic differentiation of human mesenchymal stromal cells by the synergistic action of growth factors," Journal of Maxillofacial Surgery, vol. 42, no. 8, pp. 20022009, 2014.

[147] Y. Wang, Y. Y. Huang, Y. Wang, P. Lyu, and M. R. Hamblin, "Red $(660 \mathrm{~nm})$ or near-infrared $(810 \mathrm{~nm})$ photobiomodulation stimulates, while blue $(415 \mathrm{~nm})$, green $(540 \mathrm{~nm})$ light inhibits proliferation in human adipose- derived stem cells," Scientific Reports, vol. 7, no. 1, p. 7781, 2017.

[148] P. Avci, A. Gupta, M. Sadasivam et al., "Low-level laser (light) therapy (LLLT) in skin: stimulating, healing, restoring," Seminars in Cutaneous Medicine and Surgery, vol. 32, no. 1, pp. 41-52, 2013. 